\title{
Evaluation of advance bread Wheat lines in preliminary Wheat yield trial
}

Fahim Ullah Khan ${ }^{1,2 *}$, Muhammad Khan ${ }^{1}$, Sabir Gul Khattak ${ }^{1}$, Zahid Iqbal $^{1}$, Zahid Saleem ${ }^{1}$, Javed Iqbal ${ }^{1}$ and Niaz Muhammad ${ }^{1}$

1 Department of Plant Breeding \& Genetics, The University of Agriculture Peshawar-Pakistan.

2 Barani Agricultural Research Station, Kohat-Pakistan.

*Corresponding author's email: fahimbiotech@gmail.com

Citation

Fahim Ullah Khan, Muhammad Khan, Sabir Gul Khattak, Zahid Iqbal, Zahid Saleem, Javed Iqbal and Niaz Muhammad. Evaluation of advance bread wheat lines in preliminary wheat yield trial. Pure and Applied Biology. Vol. 4, Issue 3, 2015, pp 384-388. http://dx.doi.org/10.19045/bspab.2015.43014

Received: 07/04/2015 Revised: $14 / 07 / 2015$

Accepted: $30 / 07 / 2015$

\section{Abstract}

Development of superior crop varieties is the prime objectives of all plant breeding programs. Fourteen bread wheat lines selected from $20^{\text {th }}$ Semi Arid Wheat Yield Trials received from CIMMYT-Mexico. The experiment was planted in randomized complete block design with three replications at Barani Agricultural Research Station, Kohat during 2013-14. Data were recorded on days to heading, days to maturity, plant height, tillers $\mathrm{m}^{-2}$ and grain yield. Analysis of variance revealed highly significant differences among genotypes for all the traits studied. Seven entries viz. E-304 (4033 kg ha-1), E-311 (4844 kg ha-1), E-314 (4222 kg ha'-1), E-325 (3889 kg ha$\left.{ }^{1}\right)$, E-360 (4456 kg ha-1), E-384 (4533 kg ha $\left.{ }^{-1}\right)$ and E-388 (4300 kg ha' $)$ out yielded check cultivar KT-2010 (1455 $\left.\mathrm{kg} \mathrm{ha}^{-1}\right)$ and will forwarded for multi-location testing to be released as new variety for rainfed areas.

Key words: Wheat; drought; advance lines; preliminary wheat yield trial.

\section{Introduction}

Wheat is the major food grain crop of the world and is the stpale food of millions people around the globe. Wheat is widely adaptable to wide range of climatic conditions. About $70 \%$ of the world wheat is cultivated under rainfed conditions [1]. Generally, wheat crop is affected from both heat and drought which usually occur simultaneously to cause significant reduction in yield [2]. In Pakistan, wheat is grown cultivated under rainfed condition is more than $20 \%$ of the total wheat area mainly in Khyber Pakhtunkhwa. Due to this, the average farmer yield in Khyber Pakhtunkhwa is about $1500 \mathrm{~kg} \mathrm{ha}^{-1}$, which is about half of the national yield. Low yield under rainfed conditions is generally due to low soil moisture at sowing and heat stress at reproductive stage [3].

Development of resistant variety better suited to rainfed/stress condition is the prime objective of many wheat breeding program across the globe. However, the success achieved so far is not up to the mark and need due consideration in current and future breeding schemes [4].

Therefore, the present experiment was undertaken to select early maturing, high yielding and disease resistant wheat line for rainfed areas of Khyber Pakhtunkhwa. 


\section{Materials and Methods}

This experiment was conducted at Barani Agricultural Research Station (BARS) Kohat, during 2013-2014 cropping season. The material comprised of 14 elite wheat lines selected from fifty entries received as $20^{\text {th }}$ SAWYT from CIMMYT Mexico and were screened during 2012-13 crop season. Thirteen promising lines were selected on the basis of high yield potential and disease resistances. These lines were included in preliminary wheat yield trial 2013-14 for testing against local check cultivar KT-2010. Randomized Complete Block Design with 3 replications was used. Each entry consisted of six rows with row length of 5 meters and row to row distance of $0.3 \mathrm{~m}$. Standard agronomic practices was carried out throughout the growing season. Normal dose of fertilizers i.e. N: $\mathrm{P}_{2} \mathrm{O}_{5} @ 90: 60 \mathrm{~kg} / \mathrm{ha}$ were applied at the time of sowing. Data were recorded on days to heading, days to maturity, plant height $(\mathrm{cm})$, tillers $\mathrm{m}^{-2}$ and grain yield $(\mathrm{kg} / \mathrm{ha})$. List of entries included in the trials are given in Table 1.

\section{Statistical analysis}

The data collected were subjected to analysis of variance technique appropriate for randomized complete block design using computer software Statix ver 8.1. Upon significant differences means were separated using LSD test at 5\% level of probability.

\section{Results and Discussion}

\section{Days to heading}

Mean values of 14 wheat lines for days to heading are presented in Table 2. Days to heading of fourteen wheat lines ranges from 121 to 126 with the mean value of 123 days. Entry E-314 and E-310 (126 days) took maximum days to heading, which is statistically at par with entry E-311(125 days) and entry E-313(124 days). Furthermore, minimum days to heading were recorded for check cultivar KT-2010 (121 days). The present findings are in line with the earlier research work of [5].

\section{Days to maturity:}

Mean values for days to maturity of 14 wheat lines are presented in Table 2. Days to maturity ranges from 158 to 165 with the mean value of 163 days. Entry 311, 314 and 315 (165 days) took maximum days to maturity, whereas minimum days to maturity were recorded for check cultivar KT-2010(158 days). High temperature stress induced forced maturity and thus reduce number of days to maturity. Nahar et al., [6] reported $15 \%$ reduction in maturity duration in wheat genotype due to stress condition.

\section{Plant height (cm)}

Mean values for plant height of 14 wheat lines are given in Table 2. Plant height ranges from $99.7 \mathrm{~cm}$ to 113.3 with the mean value of 106.9 $\mathrm{cm}$. Entry 315 produced tallest plants $(113.3$ $\mathrm{cm}$ ), followed by entry 324 and 384 (111.0 $\mathrm{cm}$ ) which is statistically similar with entry $388(110.3 \mathrm{~cm})$. Furthermore, check cultivars KT-2010 produced shortest plants measuring $99.7 \mathrm{~cm}$. Similar results regarding plant height was also reported in spring wheat [7].

\section{Tillers $\mathbf{m}^{-2}$}

Data pertaining tillers $\mathrm{m}^{-2}$ of 14 advance wheat lines are presented in Table 2. Tillers $\mathrm{m}^{-}$ ${ }^{2}$ ranges from 99 to 199 with the mean value of 156 . Entry 311 produced maximum tillers $\mathrm{m}^{-2}$ (199), which is statistically similar with entry 314 (188), entry 384 (185) and 360 (184). Furthermore, minimum values for tillers $\mathrm{m}^{-2}$ were recorded for entry 324 (99). Khan et al., [8] and Mehboob et al. [9] also reported variations in fertile tillers.

\section{Grain yield $\left(\mathrm{kg} \mathrm{ha}^{-1}\right)$}

Data regarding grain yield of 14 advance wheat lines are given in Table 2. Grain yield ranges from 1455 to $4844 \mathrm{~kg} \mathrm{ha}^{-1}$ with the mean value of $3593 \mathrm{~kg} \mathrm{ha}^{-1}$. Entry 311 produced maximum grain yield $\left(4844 \mathrm{~kg} \mathrm{ha}^{-1}\right)$, which is statistically at par with entry 384 $\left(4533 \mathrm{~kg} \mathrm{ha}^{-1}\right)$ and entry $360\left(4456 \mathrm{~kg} \mathrm{ha}^{-1}\right)$, whereas, minimum value for grain yield were recorded for check cultivar KT-2010 $(1455 \mathrm{~kg}$ $\mathrm{ha}^{-1}$ ). Reduction in grain yield under stress condition is reported by several researchers [911]. 
Table 1. List of entries with their parentage included in the trials.

\begin{tabular}{|c|c|c|}
\hline Entry Code & Parentage & Source \\
\hline E-304 & W15.92/4/PASTOR//HXL7573/2*BAU/3/WBLL1 & 20-SAWYT-CIMMYT Mexico \\
\hline E-302 & DHARWAR DRY & 20-SAWYT-CIMMYT Mexico \\
\hline E-310 & H45/4/KRICCHAUFF/FINSI/3/URES/PRL//BAV92 & 20-SAWYT-CIMMYT Mexico \\
\hline E-311 & VORB/SOKOLL & 20-SAWYT-CIMMYT Mexico \\
\hline E-313 & VORB/SOKOLL & 20-SAWYT-CIMMYT Mexico \\
\hline E-314 & DUCKLA/GUNDOO//SOKOLL & 20-SAWYT-CIMMYT Mexico \\
\hline E-315 & $\begin{array}{l}\text { VORB/3/T.DICCOCCON } \\
\text { PI94625/AE.SQUAROROSA (372)//3*PASTOR }\end{array}$ & 20-SAWYT-CIMMYT Mexico \\
\hline E-323 & BABAX/KS93U76//BABAX/3/2*SOKOLL & 20-SAWYT-CIMMYT Mexico \\
\hline E-324 & BABAX/KS93U76//BABAX/3/2*SOKOLL & 20-SAWYT-CIMMYT Mexico \\
\hline E-325 & MILAN/KAUZ//PRINIA/3/BAV92/4/2*SOKOLL & 20-SAWYT-CIMMYT Mexico \\
\hline E-360 & W15.92/4/PASTOR//HXL7573/2*BAU/3/WBLL1 & 20-SAWYT-CIMMYT Mexico \\
\hline E-384 & MILAN/KAUZ//PRINIA/3/BAV92/4/2*SOKOLL & 20-SAWYT-CIMMYT Mexico \\
\hline E-388 & $\begin{array}{l}\text { GK ARON/AG SECO } \\
\text { 7846//2180/4/2*MILAN/KAUZ/PRINIA/3/.... }\end{array}$ & 20-SAWYT-CIMMYT Mexico \\
\hline KT-2010 & Local Check & -- \\
\hline
\end{tabular}

Table 2. Mean squares for various morpho-physiological and yield traits of 14 bread wheat lines evaluated at BARS, Kohat during 2013-14.

\begin{tabular}{|c|c|c|c|c|}
\hline Traits & $\begin{array}{l}\text { Replication } \\
(\mathrm{df}=2)\end{array}$ & $\begin{array}{l}\text { Genotype } \\
(\mathrm{df}=13)\end{array}$ & $\begin{array}{l}\text { Error } \\
(\mathrm{df}=26)\end{array}$ & $\mathrm{CV}(\%)$ \\
\hline Days to heading & 16.6667 & $8.07 * *$ & 2.3590 & 1.25 \\
\hline Days to maturity & 0.4524 & $11.40 * *$ & 1.5037 & 0.75 \\
\hline Plant height & 6.6429 & $46.21 * *$ & 0.5659 & 0.70 \\
\hline Tillers $\mathrm{m}^{-2}$ & 13.50 & $2502.65 * *$ & 235.96 & 9.88 \\
\hline Grain yield & 3875 & $2781956 * *$ & 72540 & 7.50 \\
\hline
\end{tabular}

$\mathrm{CV}=$ Coefficient of variation and $\mathrm{df}=$ degree of freedom

$* *, *=$ significant at $1 \%$ and $5 \%$ level of probability, respectively 
Table 3. Mean performance of 14 bread wheat lines evaluated under Preliminary wheat yield trial (PWYT) at BARS, Kohat during 2013-14.

\begin{tabular}{llllll}
\hline Entry & $\begin{array}{l}\text { Days to } \\
\text { heading } \\
\text { (days) }\end{array}$ & $\begin{array}{l}\text { Days to } \\
\text { maturity } \\
\text { (days) }\end{array}$ & $\begin{array}{l}\text { Plant } \\
\text { height } \\
(\mathrm{cm})\end{array}$ & Tillers $\mathrm{m}^{2}$ & $\begin{array}{l}\text { Grain yield } \\
\left(\mathrm{kg} \mathrm{ha}^{-1}\right)\end{array}$ \\
\hline E-304 & $121 \mathrm{CD}$ & $161 \mathrm{D}$ & $104.0 \mathrm{G}$ & $169 \mathrm{~B}-\mathrm{E}$ & $4033 \mathrm{CDE}$ \\
$\mathrm{E}-302$ & $122 \mathrm{CD}$ & $164 \mathrm{~A}-\mathrm{C}$ & $105.3 \mathrm{~F}$ & $134 \mathrm{FG}$ & $2944 \mathrm{I}$ \\
$\mathrm{E}-310$ & $126 \mathrm{~A}$ & $163 \mathrm{~A}-\mathrm{C}$ & $106.7 \mathrm{E}$ & $126 \mathrm{G}$ & $3111 \mathrm{HI}$ \\
$\mathrm{E}-311$ & $125 \mathrm{AB}$ & $165 \mathrm{AB}$ & $106.7 \mathrm{E}$ & $199 \mathrm{~A}$ & $4844 \mathrm{~A}$ \\
$\mathrm{E}-313$ & $124 \mathrm{~A}-\mathrm{C}$ & $163 \mathrm{~A}-\mathrm{C}$ & $104.7 \mathrm{FG}$ & $149 \mathrm{D}-\mathrm{G}$ & $3533 \mathrm{~F}-\mathrm{H}$ \\
$\mathrm{E}-314$ & $126 \mathrm{~A}$ & $165 \mathrm{AB}$ & $101.0 \mathrm{H}$ & $188 \mathrm{AB}$ & $4222 \mathrm{~B}-\mathrm{D}$ \\
$\mathrm{E}-315$ & $123 \mathrm{~B}-\mathrm{D}$ & $165 \mathrm{~A}$ & $113.3 \mathrm{~A}$ & $130 \mathrm{G}$ & $3634 \mathrm{E}-\mathrm{G}$ \\
$\mathrm{E}-323$ & $122 \mathrm{CD}$ & $163 \mathrm{~B}-\mathrm{D}$ & $108.0 \mathrm{D}$ & $146 \mathrm{E}-\mathrm{G}$ & $3289 \mathrm{G}-\mathrm{I}$ \\
$\mathrm{E}-324$ & $122 \mathrm{CD}$ & $162 \mathrm{CD}$ & $111.0 \mathrm{~B}$ & $99 \mathrm{H}$ & $2056 \mathrm{~J}$ \\
E-325 & $123 \mathrm{CD}$ & $162 \mathrm{CD}$ & $105.7 \mathrm{EF}$ & $135 \mathrm{FG}$ & $3889 \mathrm{D}-\mathrm{F}$ \\
$\mathrm{E}-360$ & $122 \mathrm{CD}$ & $161 \mathrm{D}$ & $109.7 \mathrm{C}$ & $184 \mathrm{~A}-\mathrm{C}$ & $4456 \mathrm{~A}-\mathrm{C}$ \\
$\mathrm{E}-384$ & $122 \mathrm{CD}$ & $162 \mathrm{CD}$ & $111.0 \mathrm{~B}$ & $185 \mathrm{~A}-\mathrm{C}$ & $4533 \mathrm{AB}$ \\
E-388 & $122 \mathrm{CD}$ & $164 \mathrm{AB}$ & $110.3 \mathrm{BC}$ & $173 \mathrm{~B}-\mathrm{D}$ & $4300 \mathrm{~B}-\mathrm{D}$ \\
KT-2010 & $121 \mathrm{D}$ & $158 \mathrm{E}$ & $99.7 \mathrm{I}$ & $160 \mathrm{C}-\mathrm{F}$ & $1455 \mathrm{~K}$ \\
\hline Mean & $\mathbf{1 2 3}$ & $\mathbf{1 6 3}$ & $\mathbf{1 0 6 . 9}$ & $\mathbf{1 5 6}$ & $\mathbf{3 5 9 3}$ \\
\hline LSD(0.05) & $\mathbf{2 . 5 8}$ & $\mathbf{2 . 0 6}$ & $\mathbf{1 . 2 6}$ & $\mathbf{2 5 . 7 8}$ & $\mathbf{4 5 2 . 0 3}$ \\
\hline
\end{tabular}

\section{Conclusion and Recommendation}

Seven entries viz. E-304, E-311, E-314, E325, E-360, E-384 and E-388 were found high yielding and out yielded check cultivar KT-2010. These entries will be further tested in Advance yield trial and better performing, rust resistant lines will be sent for multi-location testing to be released as new variety for rainfed areas.

\section{References}

1. Portmann FT, Siebert S \& Doll P (2010). Mirca-2000-global monthly irrigated and rainfed crop areas around the year 2000: A new high resolution data set for agricultural and hydrological modeling. Global Biogeochem Cycles 24: 1-24.

2. Sohail M, Hussain I, Riaz-ud-din, Abbas SH, Qamar M \& Noman M (2013). Effect of split $\mathrm{N}$ fertilizer application on physioagronomic traits of wheat (Triticum aestivum L.) under rainfed conditions. Pakistan J Agric Res 26(2): 71-78.
3. Martell (2011). Crop worries from weather stress in Russia, China and Australia: Stressful hot finish in Russian grain belt'. Available online at: http://www. martellcropprojections.com/CropProduction Reports/CropWorries-From-Weather Stress- in-Russia-China-and-Australia.

4. Khan MI, Tila M, Subhan F, Amin M \& Shah ST (2007). Agronomic evaluation of different bread wheat (Triticum aestivum L.) genotypes for terminal heat stress. Pakistan $J$ Bot 39(7): 2415-2425.

5. Wardlaw IF (2002). Interaction between drought and chronic high temperature during kernel filling in wheat in a controlled environment. Ann Bot 90: 469-476.

6. Nahar K, Ahmad K \& Fujita M (2010). Phenological variation and its relation with yield in several wheat (Triticum aestivum L.) cultivars under normal and late sowing mediated heat stress conditions. Not Sci Biol 2(3): 51-56. 
7. Hossain A, Saker MAZ, Hakim MA, Lozovskaya MV \& Zvolisky VP (2011). Effect of temperature on yield and some agronomic characters of spring wheat. Int $J$ Agric Res Innov Tech 1(1\&2): 44-54.

8. Khan I, Mohammad F \& Khan FU (2015). Estimation of genetic parameters of yield and yield related traits in wheat genotypes under rainfed conditions. Intl $J$ Environ 4(2): 193-205.

9. Mahboob AS, Arain MA, Mazhar SK, Naqvi H, Dahot MU \& Nizamani NA (2005). Yield and quality parameters of wheat genotypes as affected by sowing dates and high temperature stress. Pakistan J Bot 37(3): 575-584.

10. Okuyama LA, Carlos FL \& Fernandes BNJ (2005). Grain yield stability of wheat genotypes under irrigated and non-irrigated conditions. Braz Arch Biol Technol 48(5): 697-704.

11. Shahzad K, Bakht J, Ali SW, Shafi M \& Jabeen N (2002). Yield and yield components of various wheat cultivars as affected by different sowing dates. Asian $J$ Plant Sci 1(5): 522-525. 